\title{
Raincoat design for children for age group 7-8 years: A design development case study
}

\section{REZUMAT - ABSTRACT}

Proiectarea jachetei de ploaie pentru copiii cu vârsta de 7-8 ani. Studiu de caz pentru dezvoltarea modelului

Această lucrare propune un proces de proiectare și dezvoltare a jachetei de ploaie pe baza unei analize obiective a nevoilor utilizatorilor. Jacheta de ploaie propusă este concepută pentru copiii cu vârsta cuprinsă între 7 și 8 ani. Procesul de proiectare propus începe cu interviuri personale și cu examinarea participanților. Analiza necesităților utilizatorilor va fi realizată în acest proces cu referire la categoriile de nevoi ale utilizatorilor, și anume cele funcționale, expresive și estetice. Aceste nevoi au dus la dezvoltarea ulterioară a criteriilor de proiectare. Aceste criterii au fost transformate în caracteristici ale jachetei de ploaie și utilizate în dezvoltarea unui prototip de jachetă de ploaie. În final, a fost evaluat prototipul jachetei de ploaie în ceea ce privește criteriile de proiectare. Designul final combină proprietățile funcționale, expresive și estetice dorite, așa cum sunt evidențiate prin criteriile de proiectare.

Cuvinte-cheie: considerații FEA, model de îmbrăcăminte pentru copii, proces de proiectare, analiza obiectivă, proiectarea jachetei de ploaie

\section{Raincoat design for children for age group 7-8 years: a design development case study}

This paper proposes a rain coat design and development process based on objective analysis of user needs. The proposed raincoat is developed aiming at children for age group 7-8 years. The proposed design process starts with personal interviews and participant observation. The user needs analysis will be realized in this process regarding the user need categories of functional, expressive, and aesthetic needs. These needs led to the further development of design criteria. These criteria were then translated into raincoat attributes and used in the development of a raincoat prototype. Finally, the raincoat prototype was evaluated regarding the design criteria. The final design combines the desired functional, expressive, and aesthetic attributes as outlined by the design criteria.

Key words: FEA considerations, children's garment design, design process, objective analysis, and raincoat design

\section{INTRODUCTION}

Raincoat is one of the most widely used functional garments used by children for age group 7-8 years. These children are undergoing a period of slow but steady growth, during which they are encouraged to learn some physical skills by themselves. Normally, children at this age period are very active compared with the previous age group, but they don't have a lot of outdoor activity experience. In this condition, they are easily influenced by the uncertainty of the weather. Current raincoat for children for age group 7-8 years supplied in market is adapted from that of adults, which cannot fully satisfy the needs of children. The general shape of these raincoats is in $A$ line. Their sleeves are very big. Fabrics chosen for these raincoats are heavy and unbreathable. Color story of these raincoats is also not well considered. Normally one color is used for these raincoats. Both children and their caregivers (parents, teachers...) are demanding a new functional raincoat: comfortable, highly breathable, lightweight... There is a huge gap between the consumer's perception and supplied product.

In order to improve the current design of raincoat for children for age group 7-8 years, FEA (functional, expressive, and aesthetic) needs of this group is analysed. These needs led to the further development of design criteria of the desired raincoat. FEA Consumer Needs Model is proposed by Lamb and Kallal (1992) as a consumer needs model that assesses user needs and wants by incorporating functional, expressive, and aesthetic considerations (FEA) [1]. This model has been recognized to have implications in different research. For example, Watkins (1995) extracted a design process that strengthens user needs by the use of their model [2]. Bye and Hakala (2005) developed ankle braces designed and sized specially for women which shows the critical impact of user needs [3]. Cristiano Ciappei and Christian Simoni (2009) used the FEA Consumer Needs Model to identify the key success factors engrained in the new product development practices of sport shoe companies [4]. 
Current research related to the application of the FEA Consumer Needs Model presents the fact that, even though the client defined the problem initially at the beginning of the process, designers should work through the design step of analysis and determine what the client viewed as the problem. In this process, product factors which are related to user needs can be highlighted. In this research, a FEA Consumer Needs Model is used to analysis the user needs of raincoat for children for age group 7-8 years. A group of user represents, who have deep understanding of the user need of this group is selected. Then a set of user needs criteria will be determined but this group of represents use the FEA analysis. Then, these criteria will be announced to a group of selected designers. Based on the knowledge and experience of the selected designers, these design criteria will be translated into relevantraincoat attributes. These raincoat attributes will contribute to the development of a raincoat prototype. Finally, the raincoat prototype will be evaluated regarding the user needs criteriaprovide by the group of user represents. Using this design process, the final obtained design is integrated with the desired functional, expressive, and aesthetic attributes as outlined by the design criteria.

The rest of the paper is structured as follows. In Section 2, the overall experiment design and related concepts used in the experiment design is explained. In Section 3, experiment results have been given and analysed. Finally, a conclusion is provided in Section 4.

\section{Experiment design and related concepts}

This research proposes a novel design process based on the FEA Consumer Needs Model. Two groups of different designers and user represents are involved. In this section, the overall experiment and the relevant concepts will be explained.

\section{The proposed design process}

User involvement is a widely accepted principle in a successful product development process [5]. A lack of user involvement has been repeatedly associated with failed product development projects and the benefits of user involvement have been shown in several studies [6, 7]. Analysis and integration of user needs can largely increase user involvement and lead to the success of product development [8]. The proposed design process is based on the user needs analysis using FEA Consumer Needs Model. Figure 1 describes the proposed design process.

There are two groups of people involved in this process: user represents and selected designers. The user represents are care-givers of children at the age group of 7-8. They are full-time mothers/fathers, kindergarten teachers, or primary school teachers. All of them have experience in taking care of children at the age group of 7-8. An announcement of the research purpose of this study is delivered to them and they are willing to participate in this research. There are 20 user represents who are invited. The selected designers are chosen from children's wear

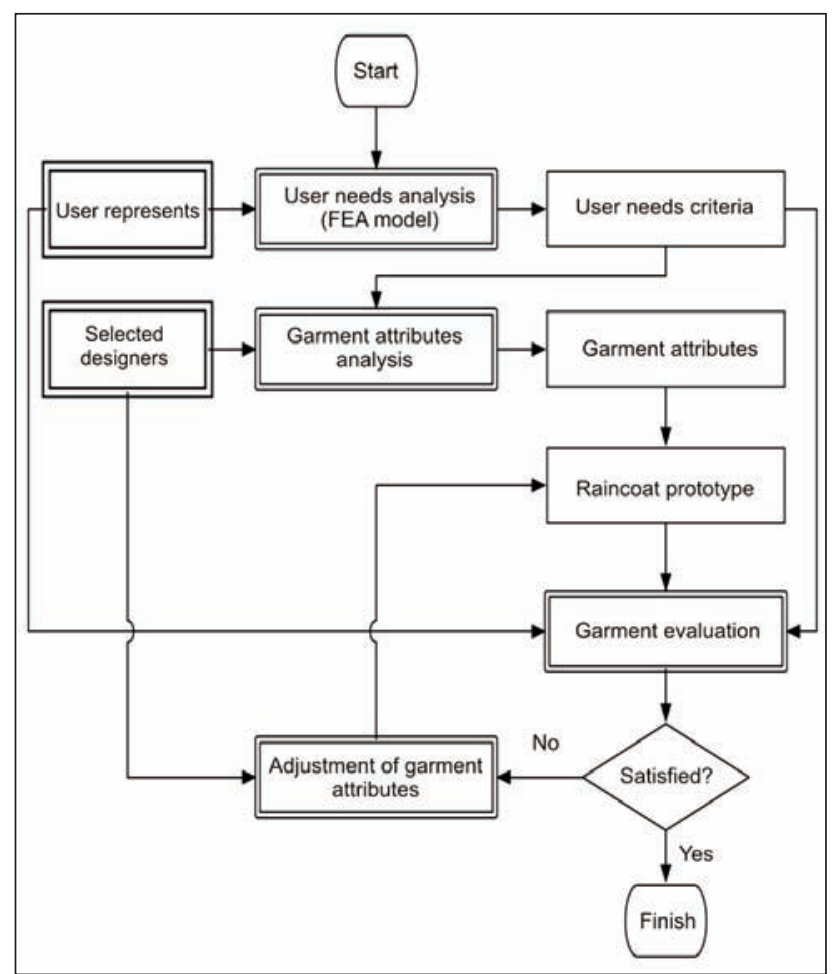

Fig. 1. Overall experiment design and data processing flow chart

fashion brands. The selected designers meet the following three requirements: (1) he/she has worked in children's wear for more than 5 years; (2) he/she has clear understanding of the physical, mental, emotional, and social characteristics of children at the age group of 7-8; (3) he/she is very experienced in garment design solutions for children's wear. There are 20 user represents who are selected.

The proposed design process starts with the user need analysis using a FEA Consumer Needs Model. The section is performed by user represents. After this section, a set of user needs criteria will be obtained. After that, based on these user need criteria, the selected designers will have a brand storm together. Related raincoat attributes will be defined based on these user need criteria. Subsequently, a raincoat prototype can be proposed when the designers reach a common conclusion. The last section of the proposed design process is the raincoat prototype evaluation. The proposed porotype will be presented to the selected user represents. They will evaluate the proposed raincoat prototype regarding the set of user needs criteria they offered. If they agree with the proposed prototype, the design process will be finished. If they don't agree, designers will adjust the raincoat attributes based on the feedback of the user represents. The sequence of designevaluate-adjustment will be repeated for several times until the final result is satisfied by the user represents.

\section{FEA Consumer Needs Model}

The FEA Consumer Needs Model is developed by Lamb and Kallal in 1992. They believe that considerations of functional, expressive and aesthetic criteria 
should be taken into apparel design process. Since 1992, the FEA Consumer Needs Model has been accepted in both research and industrial application. It is regarded as a theoretical framework to guide designers for the better understanding of the user. In applications of this conceptual framework, authors used the consumer needs focus to assess FEA criteria for products for various consumer groups. Some altered the model by not including all three criteria, or adding additional criteria. Design solutions included functional design for health and well-being, sports apparel and smart clothing, fashion apparel, textiles, costumes, fashion history as inspiration, and nonapparel items.

\section{Subjective evaluation and fuzzy set theory}

Experiments for the proposed design process are based on sensory evaluation. In this procedure, uncertain and imprecise linguistic expressions are often used by both designers and user represents. Thus, fuzzy set theory can be a relevant method for processing uncertain data obtained from sensory evaluation. Fuzzy set, as an intelligent technique, is developed to handle the vagueness of human thought which is full of uncertainty and imprecision [9]. Fuzzy set theory has wide application in the area of sensory/subjective evaluation since it has obvious advantages in dealing with uncertain data, such as linguistics and clustering [10-12]. Using fuzzy set tools, a set of linguistic terms, describing the evaluation criteria, can be quantitated in the universe of respective and discourse membership function [13]. Triangular fuzzy numbers (TFN), as a classic fuzzy set tool, are used to quantitate the utilized linguistic terms in this research.

\section{Data process using fuzzy set theory}

Based on fuzzy set theory, linguistic terms of the proposed linguistic rating scale $L_{k}$ can be quantified into Triangular Fuzzy Numbers (TFNs). A Triangular Fuzzy Number (TFN), $M$, can be denoted using $n-$ tuples formalism as $M=(I / m, m / u)$ or $M=(I, m, u)$. The parameters $I, m$ and $u$, respectively, denote the smallest possible value, the most promising value, and the largest possible value that describe a fuzzy event. Each TFN has linear representations on its left and right side such that its membership function can be defined as:

$$
\mu_{m}(x)=\left\{\begin{aligned}
0, & x \in[-\infty, l] \\
\frac{x-l}{m-l}, & x \in[l, m] \\
\frac{x-u}{m-u}, & x \in[m, u] \\
0, & x \in[u,+\infty]
\end{aligned}\right.
$$

If $M_{1}=\left(I_{1}, m_{1}, u_{1}\right)$ and $M_{2}=\left(I_{2}, m_{2}, u_{2}\right)$ are two TFNs, the operation laws between them can be defined as:

$$
\begin{aligned}
M_{1}+M_{2} & =\left(I_{1}+I_{2}, m_{1}+m_{2}, u_{1}+u_{2}\right) \\
M_{1}{ }^{*} M_{2} & =\left(I_{1}{ }^{*} I_{2}, m_{1}{ }^{*} m_{2}, u_{1}{ }^{*} u_{2}\right) \\
t^{*} M_{1} & =\left(t^{*} I_{1}, t^{*} m_{1}, t^{*} u_{1}\right)
\end{aligned}
$$

$$
\left(I_{1}, m_{1}, u_{1}\right)^{-1}=\left(1 / u_{1}, 1 / m_{1}, 1 / I_{1}\right)
$$

Using TFNs, evaluation scores given by each of the evaluators can be quantified. Table 1 presents the quantified TFNs of the proposed linguistic rating scale.

Based on the operation rules given by equation (3), (4) and (5), the evaluation scores given by each eval-

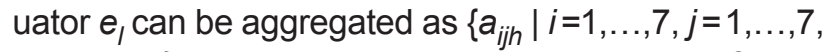
$h=1, \ldots, m\}$, where $a_{i j h}$ represents the number of evaluators who choose one certain degree. Therefore,

$$
a_{i j}=\left(\frac{1}{m} \sum_{j=1}^{l} a_{i j h} t_{1}, \frac{1}{m} \sum_{j=1}^{l} a_{i j h} t_{2}, \frac{1}{m} \sum_{j=1}^{l} a_{i j h} t_{3}\right)
$$

where $t_{1}, t_{2}$ and $t_{3}$ correspond to the value of the triangular fuzzy numbers, and they take values from table 1. Table 3 presents the aggregated evaluation matrix of the relations between different FEA considerations.

\section{EXPERIMENTS AND RESULTS DISCUSSION}

There are three experiments that are designed for the realization of the proposed design process. Experiment $\mathrm{I}$ is designed to obtain the set of user needs criteria by user represents. Experiment II is proposed to define the related raincoat attributes regarding the obtained user needs criteria by the selected designers. Experiment III is designed to evaluate the proposed raincoat prototype and give appropriate adjustment.

\section{Experiment I: User need analysis using the FEA model}

Experiment I is designed to identify the needs of children for age group 7-8 years based on FEA considerations. The invited 20 user represents form an evaluation panel for this experiment. There are two steps in Experiment I: (1) generation of user needs criteria, and (2) selection and evaluation of these user needs criteria.

First, a training section was performed. The purpose of this experiment about souring need of children for age group 7-8 years of raincoat was announced to all the panelists. After that, a brainstorming process was performed. During the brainstorming process, each of the panelists is free to access open resources (books, internet, literature...) to get information about needs for raincoat design for children of the age group of 7-8. After the brainstorming process, each trained member of the panel generated an extensive list of user needs criteria, which are in the form of words/short sentences. Then, the generated words/short sentences were collected and screened for all the members of the panel. A "round table" discussion among all the participants was carried out to vote for all the words/short sentences. There were two main principles in the election: (1) words/short sentences with repeated meaning were avoided, and (2) the selected words should try to cover all the possible design solutions. After each step, the panel leader announced the discussion result to all the panelists. Only the discussion result 


\begin{tabular}{|c|l|}
\hline User needs criteria & \multicolumn{1}{c|}{ Related raincoat attributes } \\
\hline$S_{1}$ Avoiding wind & Avoid the clothes swing caused by the wind \\
\hline$S_{2}$ Avoiding facial rain & Avoid rains go onto the face \\
\hline$S_{3}$ Good water vapor permeability & Allow water vapor pass through the garment fast \\
\hline$S_{4}$ Light weight & Make sure the raincoat is not so heavy \\
\hline$S_{5}$ Childlike pattern and color & Make the raincoat more childlike (such as use cartoon characters) \\
\hline$S_{6}$ Soft contact with skin & Make the contact part with the skin more soft \\
\hline
\end{tabular}

approved by all the panelists could be used in the following step. After that, a list of design solutions was determined, as presented in table 2 .

\section{Experiment II: Definition of raincoat attributes regarding the obtained user needs criteria}

Experiment II is performed by the selected designers. Experiment II has the similar procedure of Experiment II. There are also two steps of Experiment II: (1) generation of raincoat attributes, and (2) selection and evaluation of these raincoat attributes. After the two steps, a list of raincoat attributes was determined, as presented in table 1.

Based on these raincoat attributes, a raincoat prototype is proposed as shown in figure 2. The overall shape is similar to a jacket, which is closed by a plastic zipper with light weight. The proposed shape and construction of the raincoat can effectively avoid wind, as required by $S_{1}$. There is a transparent mask put on the face area, which can avoid rains to go onto the face, as required by $S_{2}$. Material with great vapor pass ability [14] is chosen to satisfy $S_{3}$. Such kind of material is also with light weight, which can satisfy $S_{4}$ as well. Designers proposed that the final products will be designed with different cartoon prints as a collection. As the illustration is a prototype, cartoon characters are not proposed. There are two layers for

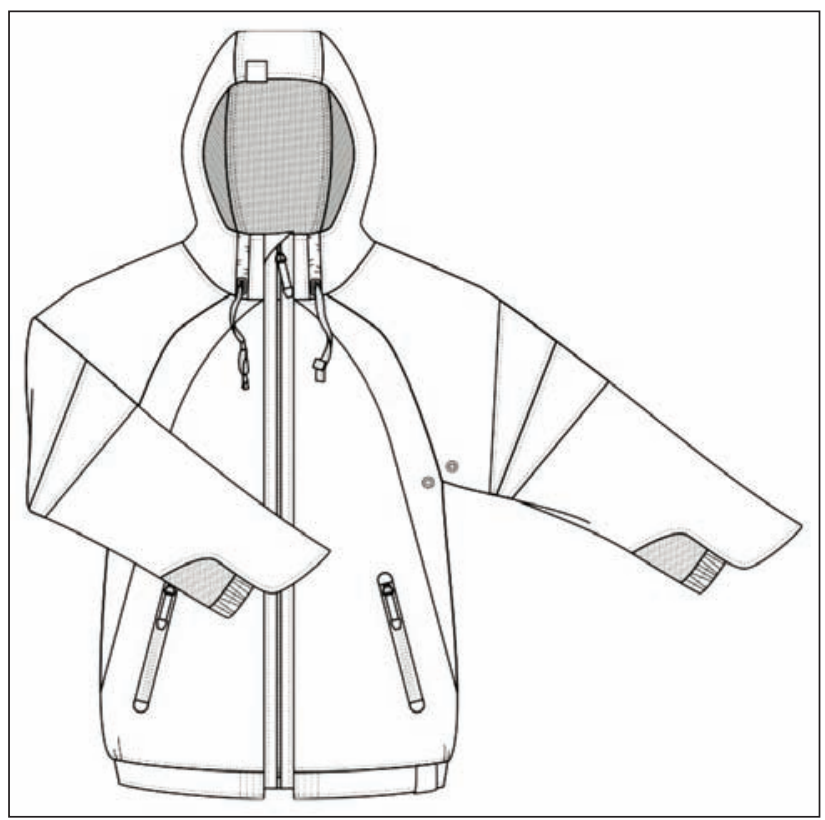

Fig. 2. Raincoat prototype for 7-8 years old children the proposed raincoat, and the lining is polyester material with soft contact.

\section{Experiment III: Garment prototype evaluation and adjustment}

In Experiment III, each of the user represents is required to give a score of the proposed raincoat prototype regarding user needs criteria shown in table 1. There is a labelprovided with the fabric content information. A scale of five evaluation degrees, ranging from $A$ to $E(A, B, C, D, E)$ are given by each user represents based on the overall evaluation of these dresses (table 3). "A" means that the best amongall these dresses, while " $E$ " means that the worst among all these dresses. A set of linguistic terms of the level of performance is applied to describe the evaluation degrees. In order to quantify the evaluation degrees, a set of fuzzy numbers is assigned to each of the linguistic term. The involved evaluation degrees, their corresponding linguistic term and fuzzy numbers are described in table 2 .

Table 2

\begin{tabular}{|c|c|c|}
\hline $\begin{array}{c}\text { Evaluation } \\
\text { degrees }\end{array}$ & Linguistic term & Fuzzy numbers \\
\hline $\mathrm{A}$ & Best (BE) & $(2.5,3,3.5)$ \\
\hline $\mathrm{B}$ & Relatively good (RG) & $(2,2.5,3)$ \\
\hline $\mathrm{C}$ & Average (AV) & $(1.5,2,2.5)$ \\
\hline $\mathrm{D}$ & Relatively poor (RP) & $(1,1.5,2)$ \\
\hline $\mathrm{E}$ & Worst (WO) & $(0.5,1,1.5)$ \\
\hline
\end{tabular}

Using this method, evaluation results of the designer can be quantified and aggregated into a group decision related to the fit effect of the proposed garment block displayed in the 3D virtual try-on.

For example, for the group perception of the invited user represents in terms of $S_{1}$ of the raincoat prototype can be formulated as a new triangular fuzzy number using equation 6 :

$$
\left(\frac{1.5 \times 2+2 \times 3}{5}, \frac{2 \times 2+2.5 \times 3}{5}, \frac{2.5 \times 2+3 \times 3}{5}\right)=(1.8,2.3,2.8)
$$

Using the same calculation process, the perception of all the designers can be aggregated in terms of different KFMs, as presented in table 4.

After that, in order to investigate the design effect of proposed raincoat prototype regarding various user needs criteria, the distance of all the aggregated evaluation scores are measured to the "Perfect" condition, 


\begin{tabular}{|c|c|c|}
\hline User needs criteria & Aggregated evaluation result & Distance to "Perfect" condition \\
\hline$S_{1}$ Avoiding wind & $(1.8,2.3,2.8)$ & 0.404145188 \\
\hline$S_{2}$ Avoiding facial rain & $(2.3,2.8,3.3)$ & 0.115470054 \\
\hline$S_{3}$ Good water vapor permeability & $(1.4,1.8,3)$ & 0.567646212 \\
\hline$S_{4}$ Light weight & $(2.2,2.9,3.4)$ & 0.11055416 \\
\hline$S_{5}$ Childlike pattern and color & - & - \\
\hline$S_{6}$ Soft contact with skin & $(2.4,2.9,3.4)$ & 0.057735027 \\
\hline
\end{tabular}

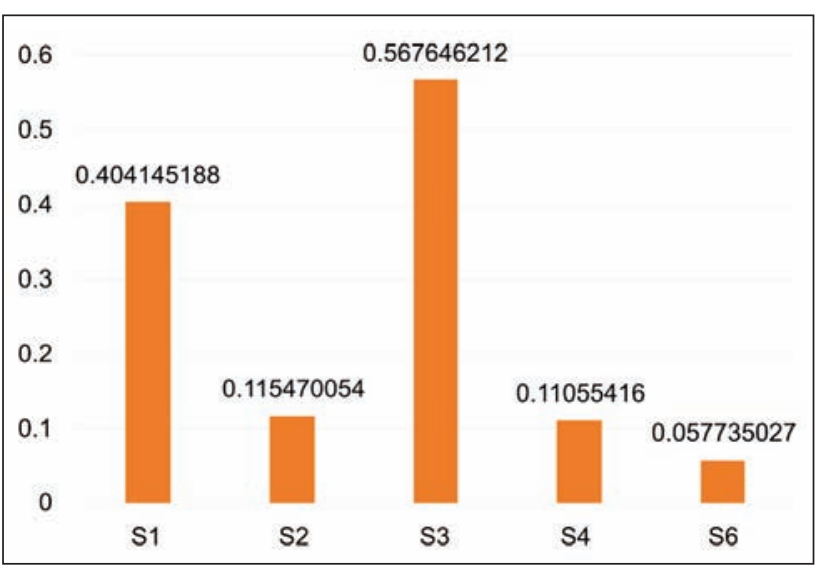

Fig. 3. Design effect of the proposed raincoat prototype regarding the user needs criteria

whose corresponding TFN is $(2.5,3,3.5)$. When the distance is shorter, the satisfaction is higher. For example, using equations $2-6$, the fit effect of $F_{A 1}$ can be calculated as:

$$
\sqrt{\frac{1}{3}\left[(1.8-2.5)^{2}+(2.3-3)^{2}+(2.8-3.5)^{2}\right]}=0.4
$$

Similarly, all the aggregated TFNs and corresponding distance to the "Perfect" condition can be formulated as presented in table 3 .

Figure 3 presents the design effect of the proposed raincoat prototype regarding the user needs criteria. It can be found that, the distances of $S_{1}$ and $S_{3}$ to the "perfect" condition is rather long, which means that the design effect of the proposed raincoat prototype is not satisfied by the user represents regarding $S_{1}$ and $S_{3}$.

Based on the result obtained, a group discussion was organized again to adjust the proposed raincoat prototype. The same evaluation procedure that was applied at the previous stage was carried out again. The sequence of Design - Evaluation - Adjustment can be performed repeatedly until a satisfying design solution is obtained. Figure 4 presents the modified raincoat prototype.

For the adjusted vision of raincoat prototype, a vest is designed inside. The inside vest is more stick to the

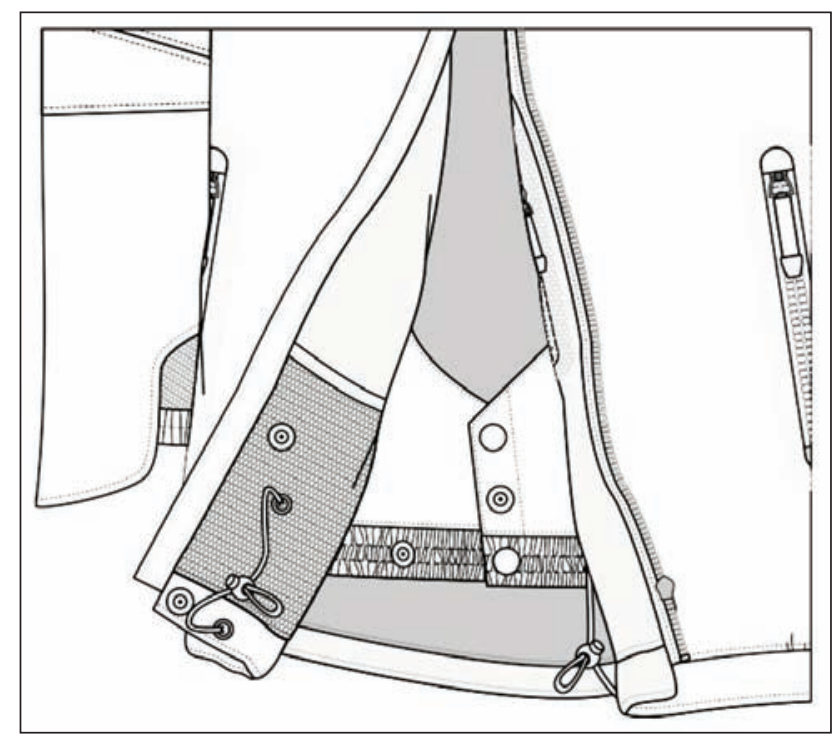

Fig. 4. Modified raincoat prototype with enhanced functional design

body, which can effectively avoid wind, as required by $S_{1}$. Besides, as the outer layer of the raincoat is a little bit loose. There is a gap between inside and outside layers, which can make it possible to the vaper release, as required by $S_{3}$.

\section{CONCLUSION}

In this research, a raincoat design and development process is developed based on FEA Consumer Needs Model. The proposed design process starts with personal interviews and participant observation. The user needs analysis will be realized in this process regarding the user need categories of functional, expressive, and aesthetic needs. These needs led to the further development of design criteria. These criteria were then translated into raincoat attributes and used in the development of a raincoat prototype. Finally, the raincoat prototype was evaluated regarding the design criteria. A case study is given for the development of a raincoat aiming at children for age group 7-8 years. The final design combines the desired functional, expressive, and aesthetic attributes as outlined by the design criteria.

\section{BIBLIOGRAPHY}

[1] Lamb, J.M., Kallal, M.J. A conceptual framework for apparel design, In: Clothing and Textiles Research Journal, vol. 10, no. 2, pp. 42-47, 1992. 
[2] Watkins, S.M. Using the design process to teach functional apparel design, In: Clothing and Textiles Research Journal, vol. 7, no. 1, pp. 10-14, 1988.

[3] Bye, E., Hakala, L. Sailing apparel for women: A design development case study, In: Clothing and Textiles Research Journal, vol. 23, no. 1, pp. 45-55, 2005.

[4] Ciappei, C., Simoni, C. Drivers of new product success in the Italian sport shoe cluster of Montebelluna, In: Journal of Fashion Marketing and Management: An International Journal, vol. 9, no. 1, pp. 20-42, 2005.

[5] Hong, Y., Bruniaux, P., Zeng, X., Curteza, A., Chen, Y. Visual-simulation-based Personalized Garment Block Design Method for Physically Disabled People with Scoliosis (PDPS), In: Autex Research Journal

[6] Hong, Y., Zeng, X., Bruniaux, P., Liu, K. Interactive virtual try-on based three-dimensional garment block design for disabled people of scoliosis type, In: Textile Research Journal, vol. 87, no. 10, pp. 1261-1274, June 1, 2017.

[7] Yan Hong, Xianyi Zeng, Kaixuan Liu, Yan Chen, Min Dong, Virtual reality based collaborative design method for designing customized garment of disabled people with scoliosis, In: International Journal of Clothing Science and Technology, vol. 29, no. 2, pp. 226-237, 2017.

[8] Florescu, M.S., Ivanov, F. Globalization as a factor of influence on the R\&D activity and the case of the textile industry in Romania/Globalizarea ca factor de influenta asupra activitatii de C\&D. Cazul industriei textile din România, In: Industria Textila, vol. 67, no. 5, p. 345, 2016.

[9] Hong, Y., Zeng, X., Wang, Y., Bruniaux, P., \& Chen, Y. CBCRS: an open case-based color recommendation system, In: Knowledge-Based Systems, vol. 141, pp. 113-128, 2018.

[10] Hong, Y., Bruniaux, P., Zeng, X., Curteza, A., Liu, K. Design and evaluation of personalized garment block design method for atypical morphology using the knowledge-supported virtual simulation method, In: Textile Research Journal, vol. 0, no. 0, p. 0040517517708537.

[11] Chen, Y., Zeng, X., Happiette, M., Bruniaux, P., Ng, R. and Yu, W. A new method of ease allowance generation for personalization of garment design, In: International Journal of Clothing Science and Technology, vol. 20, no. 3, pp. 161-173, 2008.

[12] Hong, Y., Zeng, X., Bruniaux, P. Knowledge acquisition and modeling of garment product development, In: Uncertainty Modelling in Knowledge Engineering and Decision Making: Proceedings of the 12th International FLINS Conference (FLINS 2016), Roubaix, 2016, vol. 10, pp. 438-444: World Scientific.

[13] Zadeh, L.A. Outline of a computational theory of perceptions based on computing with words, In: Soft computing and intelligent systems: theory and applications. Academic Press, London, pp. 3-22, 2000.

[14] Surdu, L., Cioara, I., Ghituleasa, C., Rădulescu, I.R. Comfort properties of multilayer textile materials for clothing, In: Industria Textila, vol. 64, no. 2, pp. 75-79, 2013.

\section{Authors: \\ LINZI PU1 \\ YAN HONG ${ }^{2}$ \\ MELISSA WAGNER ${ }^{2,3,4}$ \\ PEIGUO WANG ${ }^{1}$ \\ MULAT ABTEW2,3,4}

${ }^{1}$ School of Arts and Garment Engineering, Changshu Institute of Technology, Suzhou, 215021, Jiangsu, China ${ }^{2}$ College of Textile and Clothing Engineering, Soochow University, Suzhou 215021, China

${ }^{3}$ GEMTEX, ENSAIT, 2 allée Louise et Victor Champier, 59056 Roubaix Cedex 1, France

4 University Lille Nord de France, France

Corresponding author:

PEIGUO WANG

e-mail: peiguo.wangcn@gmail.com 